\title{
CREATING A SYSTEM FOR UPSTREAM - DOWNSTREAM FISH MIGRATION OVER THE FIRST AND THE SECOND DISCHARGE SILLS DOWNSTREAM OF MĂNĂŞTUR DAM ON THE SOMEŞUL MIC RIVER (CLUJ NAPOCA, TRANSYLVANIA, ROMANIA)
}

Răzvan VOICU* and Eric MERTEN **

* National Institute of Hydrology and Water Management, Department of Eco-Hydrology, BucureștiPloiești Avenue 97, Romania, RO-013686,rzvnvoicu@yahoo.com

** Wartburg College, Waverly Boulevard 100, Iowa, USA, IA-50677, eric.merten@wartburg.edu

DOI: 10.1515/trser-2015-0025

KEYWORDS: lotic ecosystem, fish migration, Someșul Mic River, connectivity.

ABSTRACT

The paper presents a case study that proposes a technical solution to facilitate fish migration upstream the discharge sills located on Someşul Mic River, near the Mănăştur Dam from the Cluj Napoca Town. The proposed solution provides building of a system to facilitate fish migration, placed on the left bank of Someşul Mic River, meant to restore the longitudinal connectivity of Someşul Mic River in front of the Mănăştur Dam discharge sills and to facilitate the access of the migratory fish species to upstream breeding habitats. The proposed migration system is based on using traction of winches and the gravitational fall of water and will lead to the restoration of the longitudinal connection of the Someşul Mic River near the weir selected as case study, and will reconnect a habitat with a length of around one $\mathrm{km}$, that will contribute to insuring of optimal conditions for developing migratory fish species present in the area.

RESUMEN: Creación de un sistema bidireccional para facilitar la migración de peces en el primero y segundo alféizar de descarga de la presa Mănăștur, en el río Someșul Mic (Cluj Napoca, Transilvania, Rumania).

En este artículo se propone una solución técnica para facilitar la migración de peces hacia el alféizar de descarga en el río Someşul Mic, cerca de la presa Mănăştur, en el poblado de Cluj Napoca. La solución consiste construir un sistema en el lado izquierdo del río Someşul Mic, frente al alféizar de descarga de la presa Mănăştur, con el fin de facilitar el acceso de peces migratorios a sus hábitats reproductivos, río arriba. Este sistema se vale tanto de la tracción de malacates como de la caída del agua por gravedad, y permitirá restaurar la conectividad longitudinal del río Someşul Mic a la altura de la presa; este sistema, asimismo, volverá a conectar un hábitat de aproximadamente un km de largo, que contribuirá a asegurar que se den las condiciones óptimas para el desarrollo de los peces migratorios presentes en el área.

REZUMAT: Crearea unui sistem pentru migrarea peștilor amonte - aval de cele două praguri deversoare (primul și al doilea) situate aval de barajul Mănăștur de pe râul Someșul Mic (Cluj Napoca, Transilvania, România).

În această lucrare este prezentată o soluţie tehnică propusă pentru facilitarea migrării ihtiofaunei peste ambele praguri de fund de lângă Barajul Mănăştur, amplasat pe Someşul Mic, la Cluj Napoca. Soluţia presupune realizarea unui sistem de migrare lângă malul stâng al râului Someșul Mic şi va avea ca scop refacerea conectivităţii longitudinale a râului Someşul Mic, în dreptul pragurilor de fund de lângă Barajul Mănăştur şi facilitarea accesului speciilor de peşti migratori din zona de studiu către habitatele de reproducere din amonte. Realizarea sistemului de migrare propus, bazat pe folosirea tracțiunii troliilor și a căderii gravitaţionale a apei, va asigura reconectarea unui habitat cu o lungime de aproximativ un $\mathrm{km}$ şi va contribui la crearea unor condiţii optime pentru dezvoltarea speciilor de peşti prezente în zonă. 


\section{INTRODUCTION}

The subject of this article represents a European theme of great topicality and interest regarding the restoration of the water courses affected by the hydromorphological pressures created by the presence of transversal works which lead to the interruption of longitudinal connectivity of rivers, stopping the fish migration and modifying the flow regime. Restoring the longitudinal connectivity of the river will contribute to ensure protection of protected fish species. All fish species present in the study area are part of the Someşul Mic River (Fig. 1) freshwater ecosystem situated in Transylvania, an area that face significant watershed management risks. Someşul Mic River is channelled and covered by concrete and has not meandered in the village of Cluj, a fact which has a negative impacts on the dynamics of the watercourse.

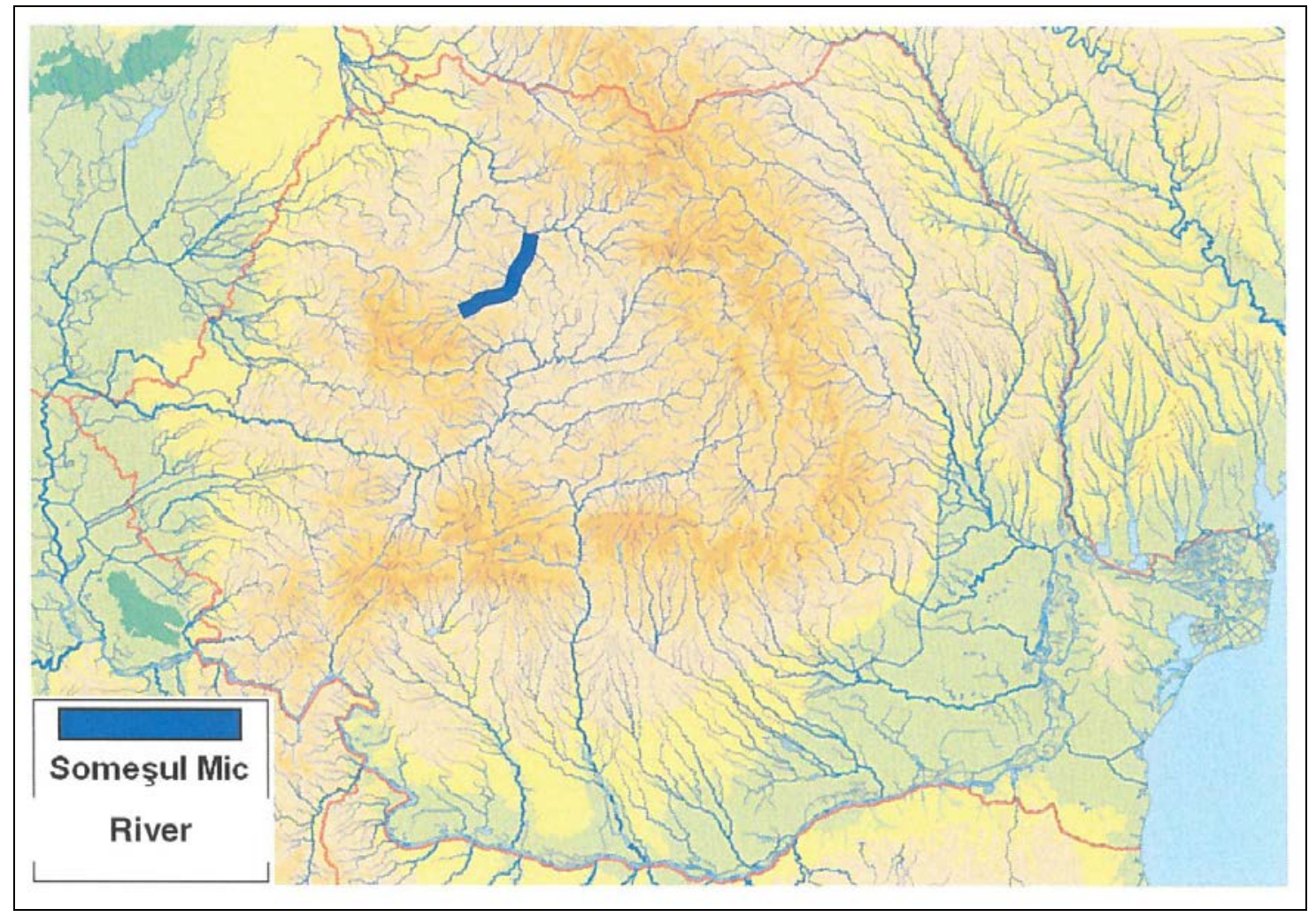

Figure 1: Someșul Mic River localization in the north-western part of Romania.

There are many hydrotechnical facilities along the Someşul Mic River, a river in northwestern Romania (Cluj County), including discharge sills (Fig. 2). In the city of Cluj Napoca there are sills near: "U" Cluj Stadium, Opera, and Astoria buildings, etc. These discharge sills seriously affect the connectivity of the Someşul Mic River, strongly reducing its biodiversity and ecological valence, implicitly. The need for longitudinal connectivity of watercourses represents an essential condition for the Water Framework Directive approved by the European community and, therefore, it should be applied to all streams containing migratory species. This article represent a part of a complex study regarding the restoration of longitudinal connectivity of Someşul Mic River accomplished in a framework of a more large Programme of Measures for restoring longitudinal and lateral connectivity of Someşul Mic River. 


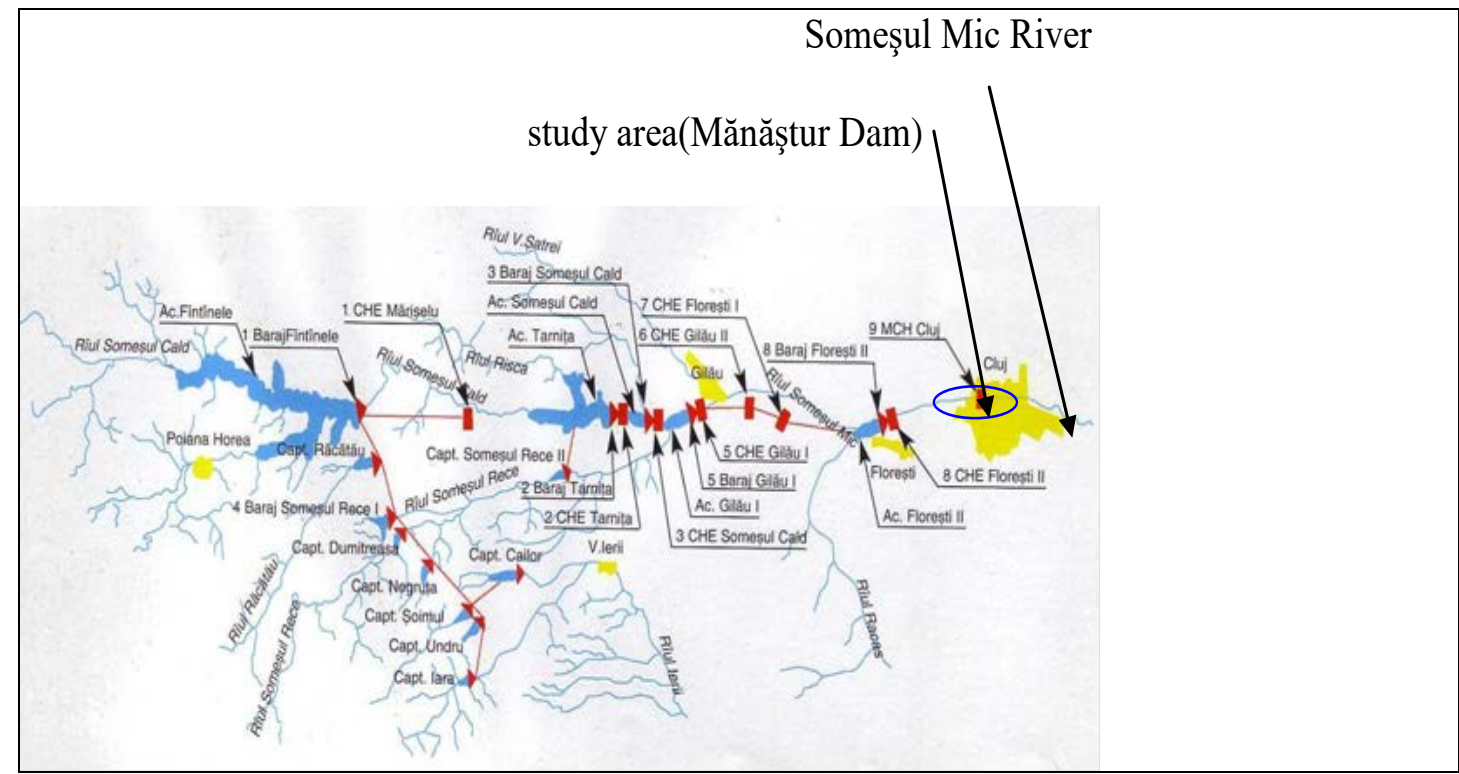

Figure 2: Hydrotechnical constructions on the Someşul Mic River

(www.hidroconstructia.com).

The subject of this case study proposes an ecotechnical solution consisting of the frontal connectivity in the city of Cluj Napoca. The solution proposed for fish fauna migration upstream - downstream of the spillway sills situated at the City Hall of Cluj Napoca is practical, it can be developed without expensive technology and does not affect the discharge sills structure and associated construction. This solution for ichthyofauna migration upstreamdownstream from the dams involves average costs and can be applied anywhere in the world.

\section{RESULTS AND DISCUSSION}

Fish passage is an important design consideration for dams around the world, and many dams are now being retrofitted to facilitate upstream movement of ichthyofauna over these structures. The success of fish passage systems is variable, suggesting a need for continued work designing and testing new systems. Although the impacts of dams on geomorphology and thermal regimes remain, fish passage systems can provide some relief for migratory fish species in cases where dam removal is not an option.

The systems presented here are intended for situations like the first and second discharge sills downstream of Mănăştur dam on the Someşul Mic River in Cluj Napoca, Romania (Fig. 1). The water speed downstream of Mănăştur dam is about one $\mathrm{m} / \mathrm{s}$ and the water flow about $5.5 \mathrm{~m}^{3} / \mathrm{s}$. River slope is 0.5 percent (\%). The present fish species include nase (Chondrostoma nasus) which is protected by the Bern Convention as well as barbel (Barbus meridionalis) which is protected by the Habitats Directive.

In order for fish to move past the first discharge sill (Fig. 4) a circular concrete basin provided with an opening should be constructed downstream of the discharge sill (Fig. 3). The opening through which fish must go should be placed downstream, its axis forming an angle of $40^{\circ}$ from the $\mathrm{x}$-coordinate and $60^{\circ}$ from the ordinate (Fig. 4). In this case the distance between the circular basin and the discharge sill is four meters. 


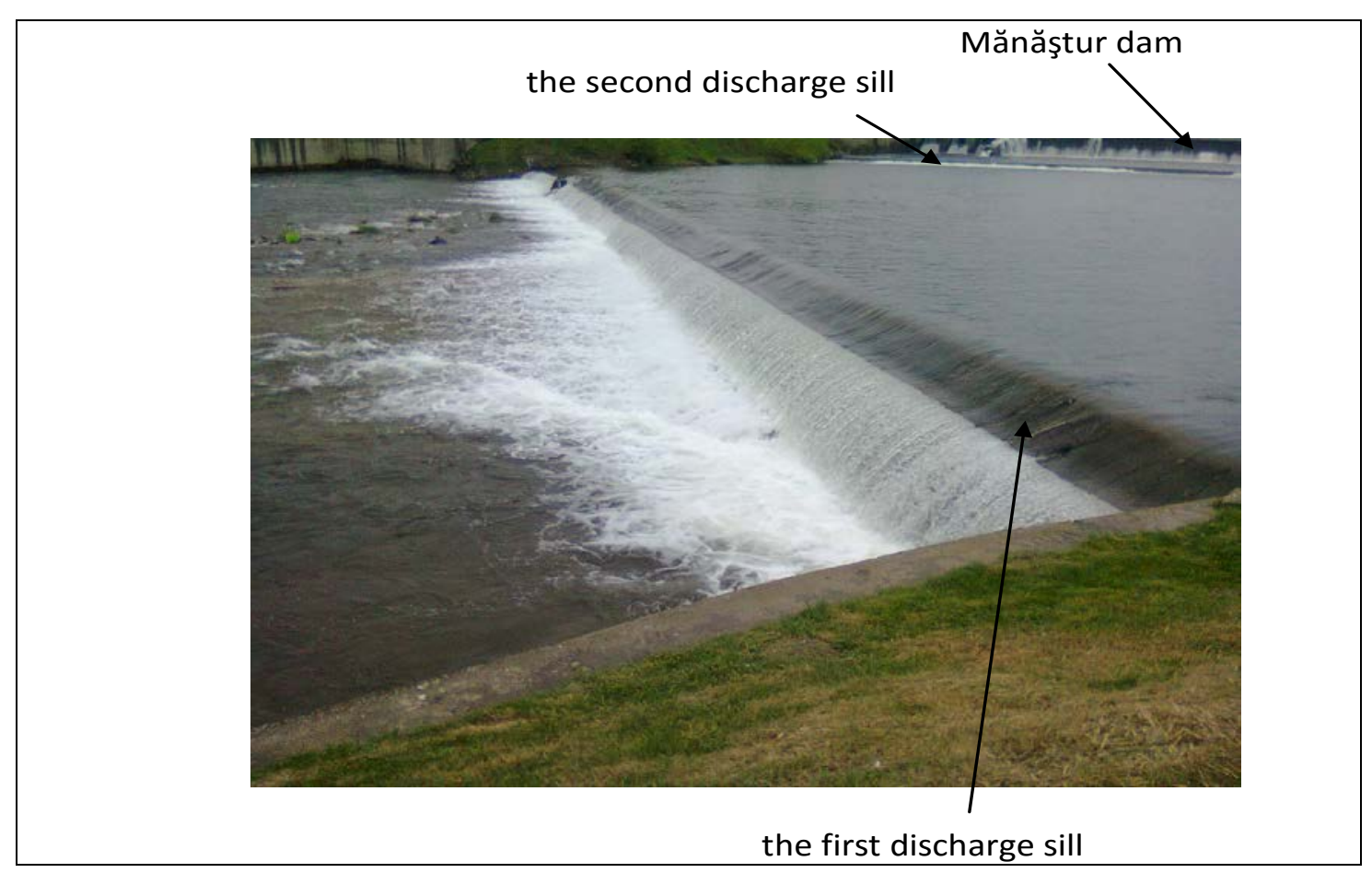

Figure 3: The first discharge sill downstream of Mănăştur dam.

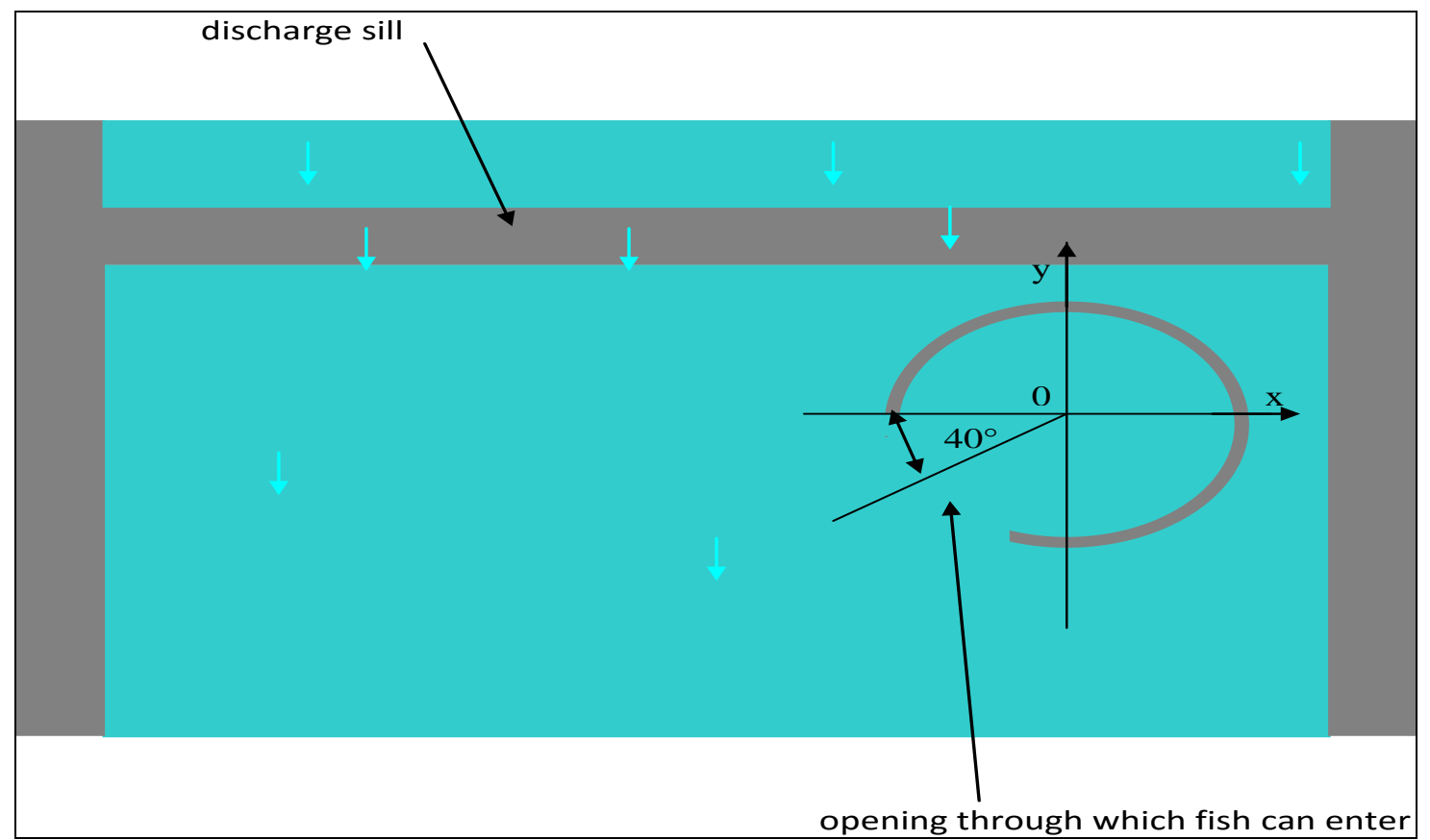

Figure 4: Positioning the circular concrete basin and opening through which fish can enter basin - indicative scheme. 
Fish must be directed towards the circular concrete basin entrance using generators of electric fields with low amperage for blocking or redirecting fish, positioned downstream of the discharge sill (Fig. 4). In this case study more generators positioned parallel to the right bank and downstream of the circular concrete basin are required, and other generators will be positioned parallel to the left bank right next to the circular concrete basin. Also, some highly resistant woven plastic fences will be used for redirecting. This plastic fence (parallel to the left bank) is fixed to the riverbed by the means of metal dowels and, at the top it is connected to buoys. The other woven plastic fence forms an angle of about $30^{\circ} \mathrm{C}$ in relation to the discharge sill and it is also fixed to the bed by the means of metal dowels and connected to buoys (Fig. 4). The plastic fence is placed during upstream migration season and removed at other times to reduce fouling with leaves or other debris. Redirection system of fish is common and useful for many species not only existing in Someșul Mic River.

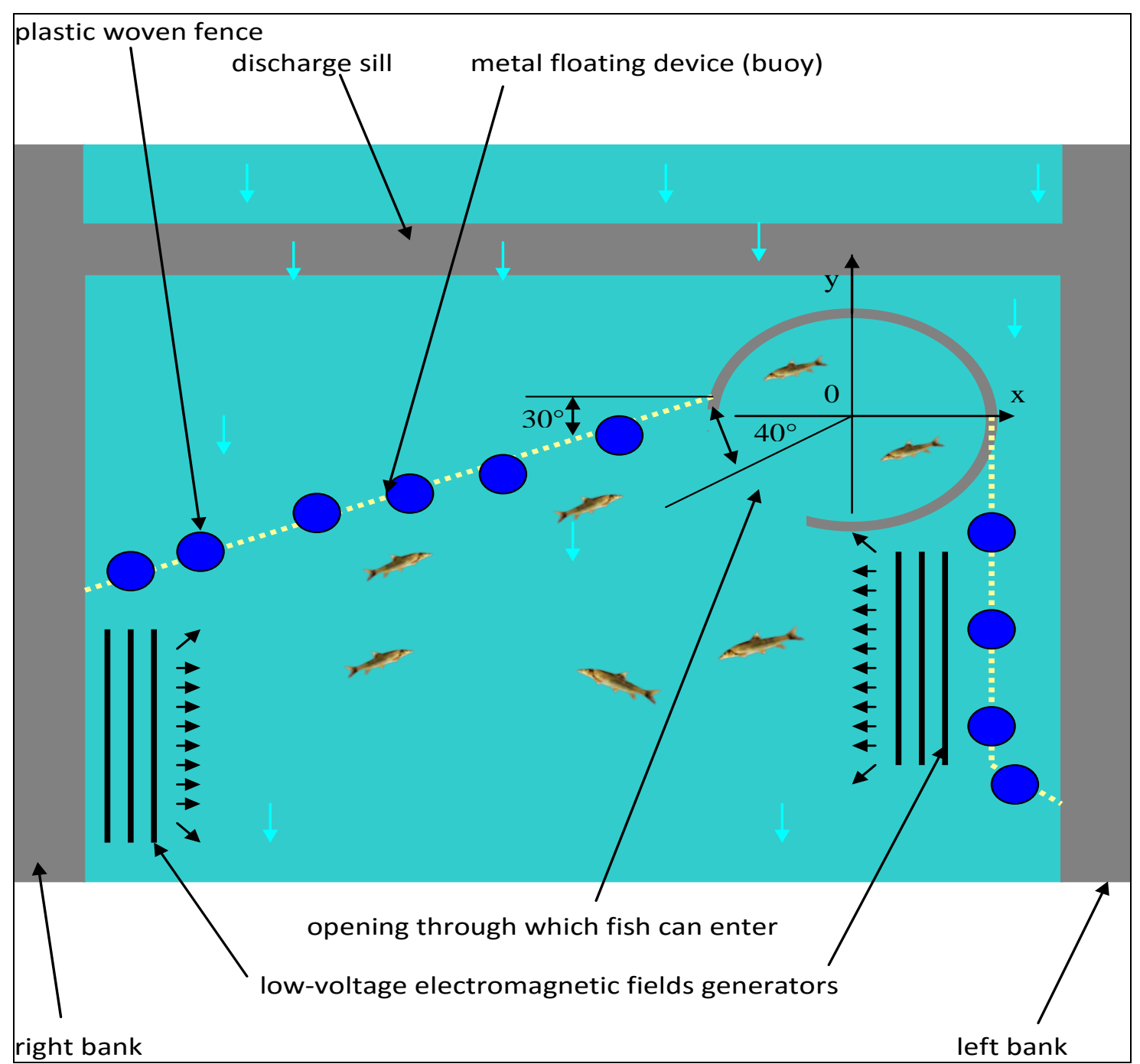

Figure 5: Positioning both the plastic fence and low-voltage electromagnetic fields generators - indicative scheme. 
Eight spacers are fixed to the circular concrete basin and other four stainless steel bars are fixed to these spacers.

Two metal clamps are fixed for each metal bar and some resistant plastic disc is fixed to all clamps (Fig. 5) fixed on an inclined plane (Fig. 6). each of them.

Each necklace slides on the bar it is set. Spacers are one $\mathrm{cm}$ long and two $\mathrm{cm}$ thick

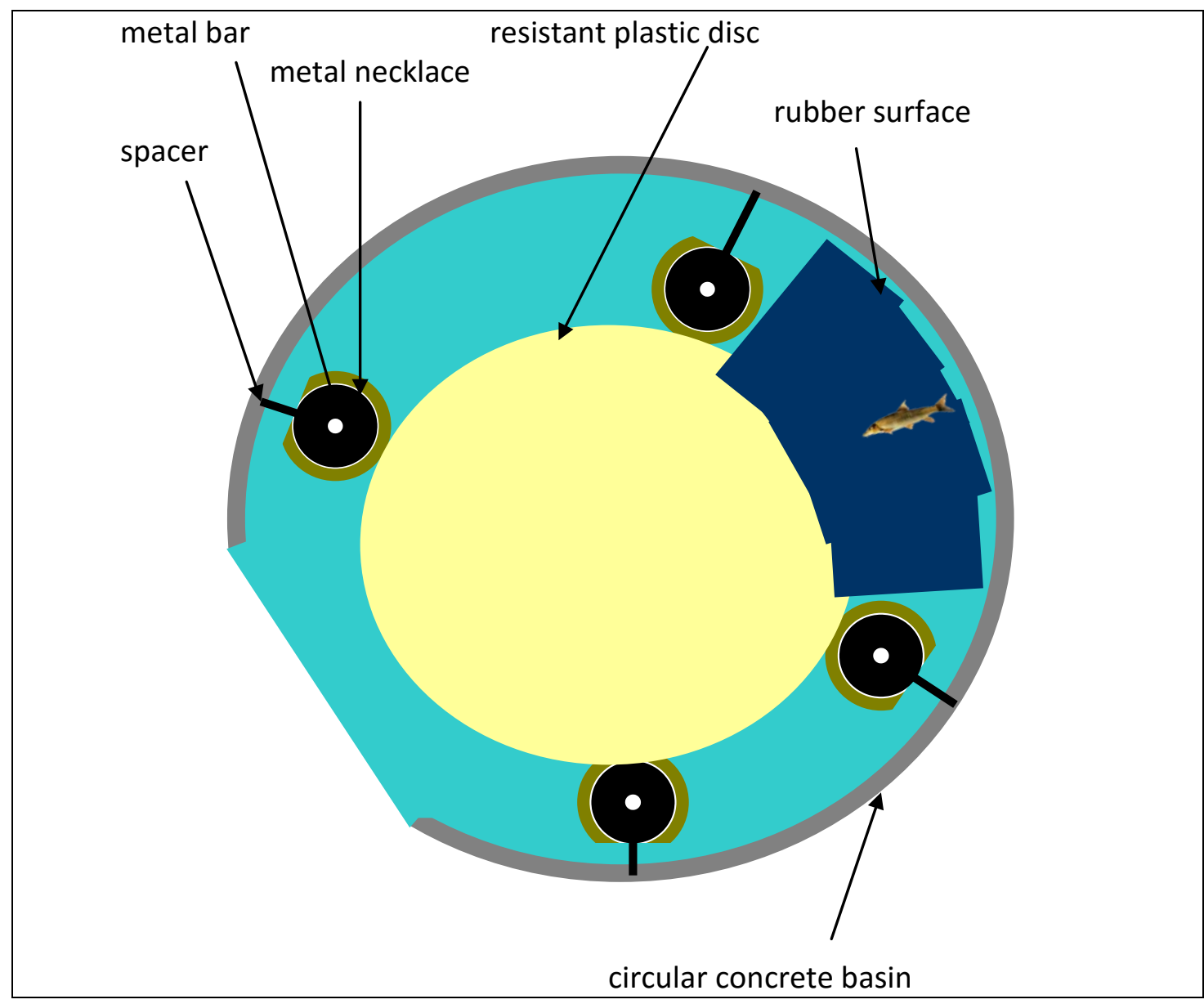

Figure 6: Fixing the resistant plastic disc to the concrete circular basin - indicative scheme. 
Spacers are one $\mathrm{cm}$ long and two $\mathrm{cm}$ thick each. The calculations are made according to the biomass to be transported. The plastic disc thickness is five $\mathrm{cm}$. The thickness of the bars on which the two cm-thick metal necklaces are fixed is three $\mathrm{cm}$. From all these it follows that the plastic resistant disc diameter is $3.939 \mathrm{~m}$. Between the necklace and metal bar there is a space of about a quarter of a millimetre which allows the necklace to slide on the bar. Within the remaining space between the concrete circular basin and plastic resistant disc, some rubber surface will be fixed to prevent the ichthyofauna from falling through the free space between the durable plastic disc and circular basin when the disc rises vertically (Fig. 6). One centimeter away from the basin is enough for rubber membrane that holds water needed to transport fish safely.

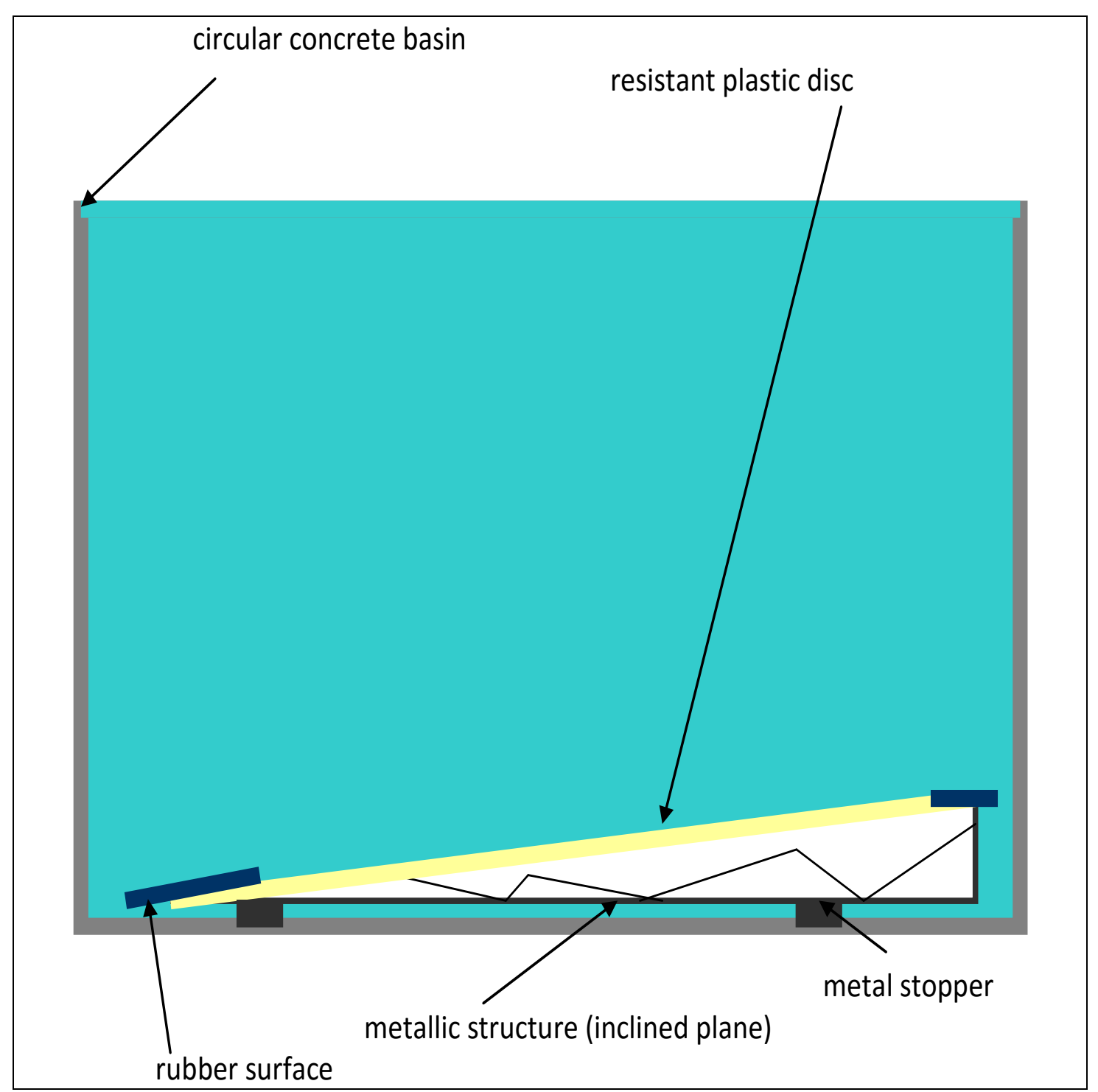

Figure 7: Fixing the resistant plastic disc metal inclined plane basin - indicative scheme. 
Lifting and lowering the resistant plastic disk and the metal structure on which it is fixed is performed by using a pulley fixed to a concrete pillar (Fig. 7).

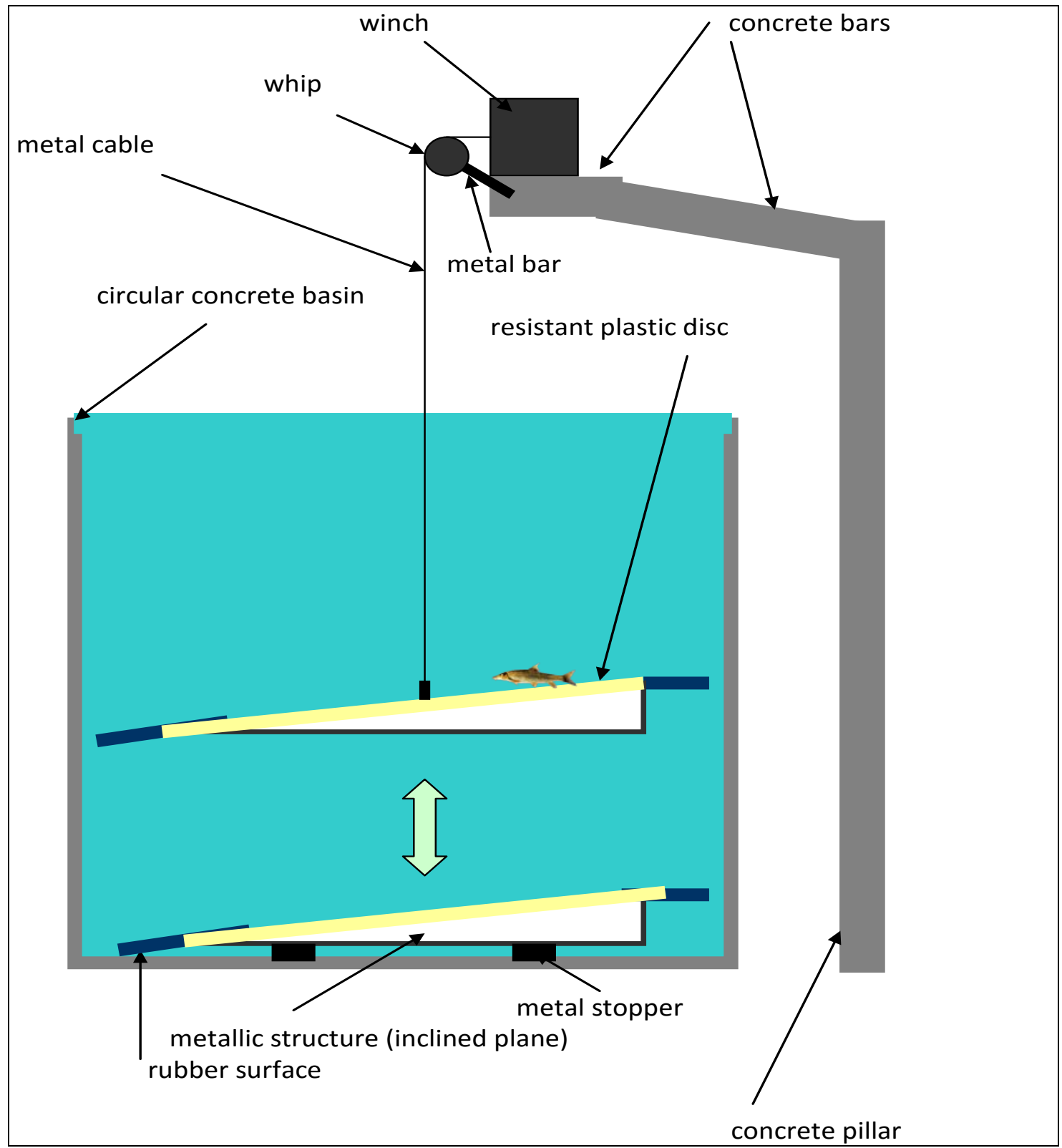

Figure 8: Positioning the winch on the concrete bar (downstream solution) basin - indicative scheme. 
When the metal structure reaches its peak, all fish slip on the resistant plastic disc into a plastic tube fixed right above the discharge sill (Fig. 8).

Fish cannot dart out of the structure (outside the basin) because lifting will be done quickly and the resistant plastic will rise above the door thereby blocking the exit.

Another important issue is that the rubber membrane between the pool and inclined plane will protect the fish. Some water will remain on the resistant plastic disc until it reaches maximum so that fish can go easily down the channel over the discharge sill.

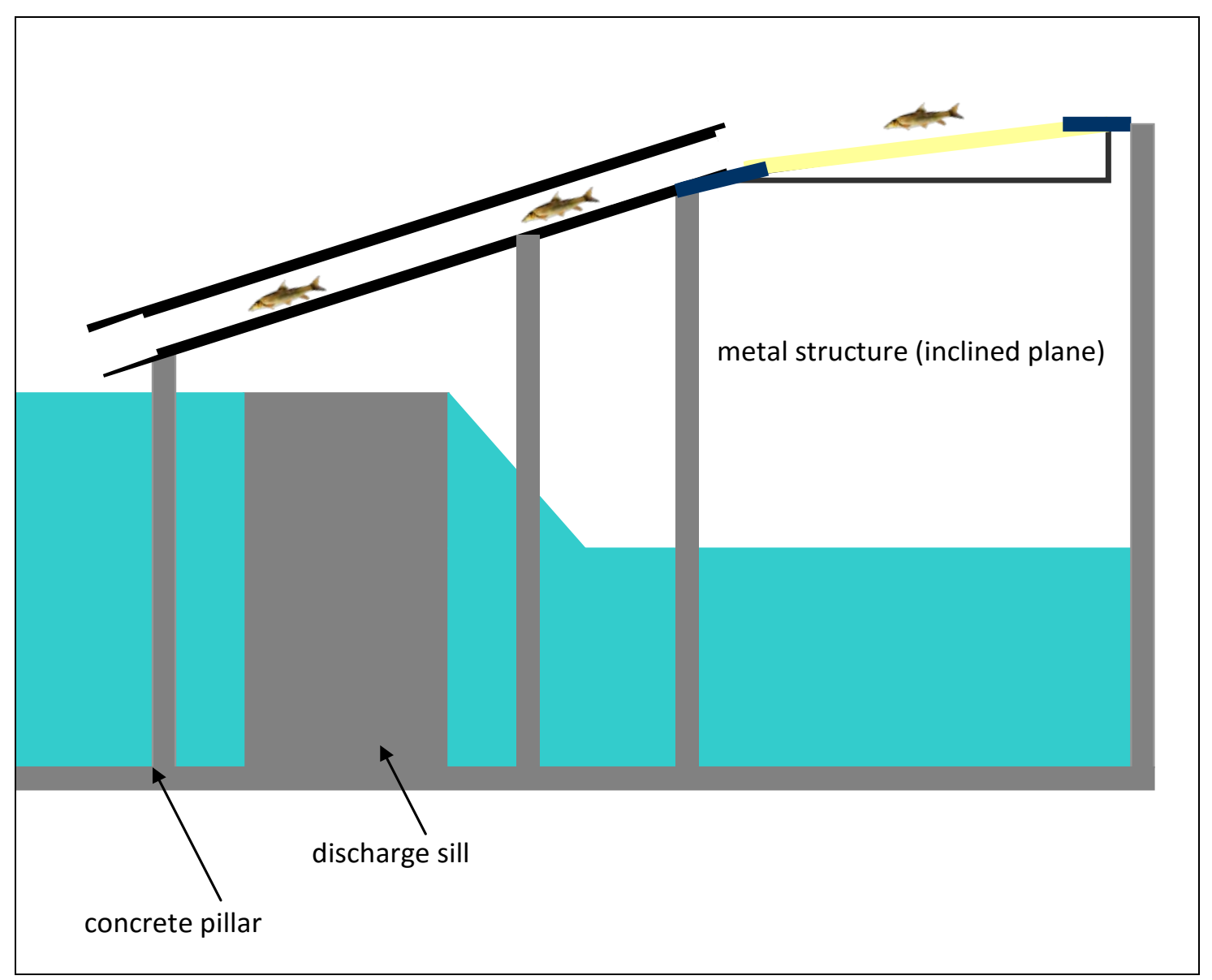

Figure 9: Fixing the plastic canal above the discharge sill, metal structure (inclined plane) basin - indicative scheme. 
When the metal comes back to its initial position it presses on a spring door that, when at the maximum position, completely blocks water from entering the circular concrete basin (Fig. 9).

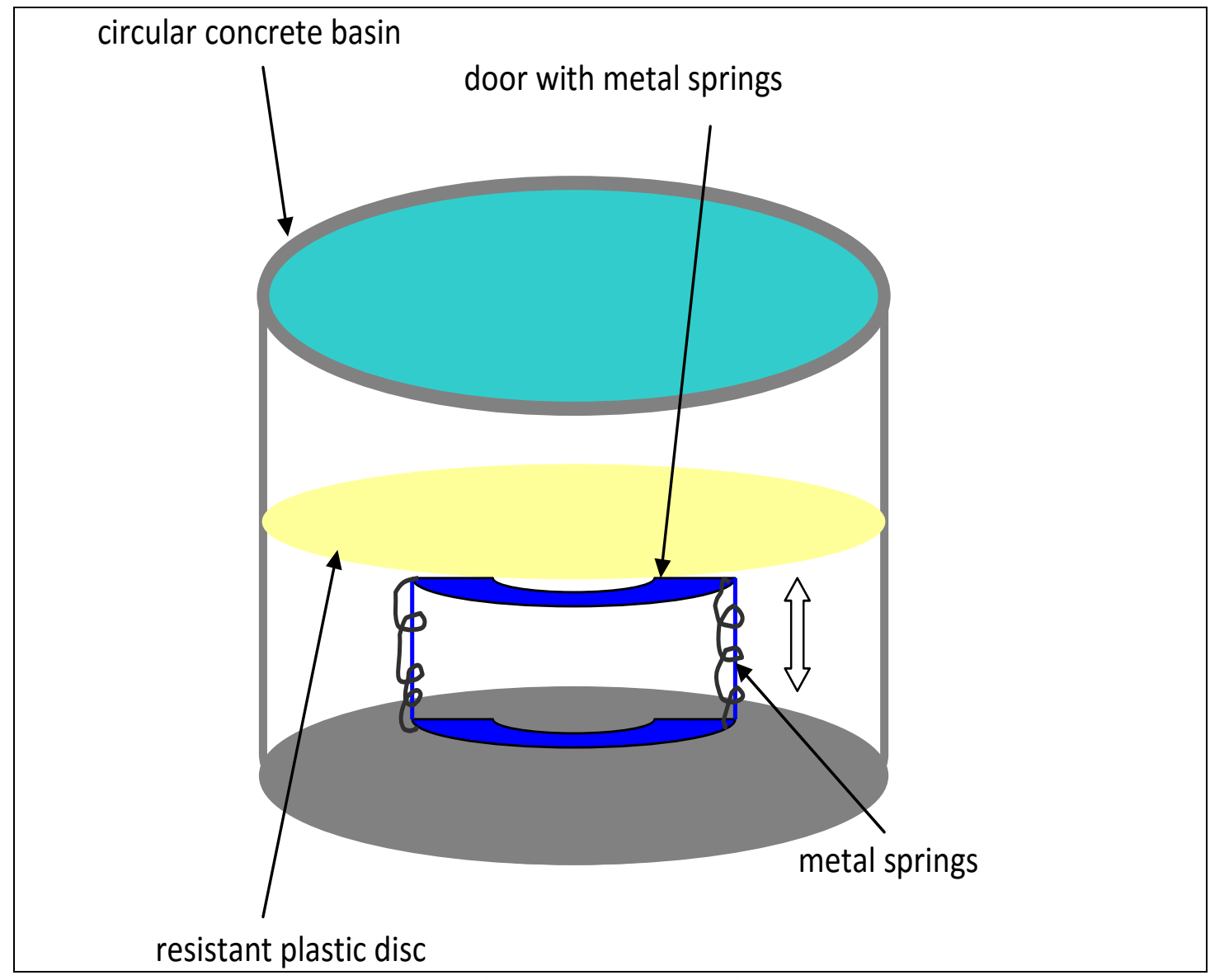

Figure 10: Positioning the fish entrance door of the circular concrete basin

- indicative scheme.

The resistant plastic disc remains in the maximum position for approximately 15 seconds, and then returns to its original position by the means of the pulley. The maximum height reached by the resistant plastic disc is $35 \mathrm{~cm}$ and $40 \mathrm{~cm}$ respectively, lower than the crest of the circular concrete basin, which does not allow fish to jump out of the pool. Thus all ichthyofauna on the plastic disc reaches upstream of the discharge sill. The efficiency of the system is complete and can operate day and night for many species of fish, salmonids included. Protection of fish is total, as there is no risk of fish injury as in case of the old fish ladders provided with concrete slots.

Inside the basin there are some sensors for ichthyofauna triggering up and down the plastic resistant disc. The spring door closes completely before resistant plastic disk reaches the maximum position, not allowing the fish to enter the basin. All components are stainless steel and the energy consumption (sources include: national network, solar energy, or batteries) is rather reasonable. 
In order to obtain an upstream - downstream solution, the same sizes circular concrete basin will be built. The redirecting system is symmetrical to the first one and following the same principle (Fig. 10).

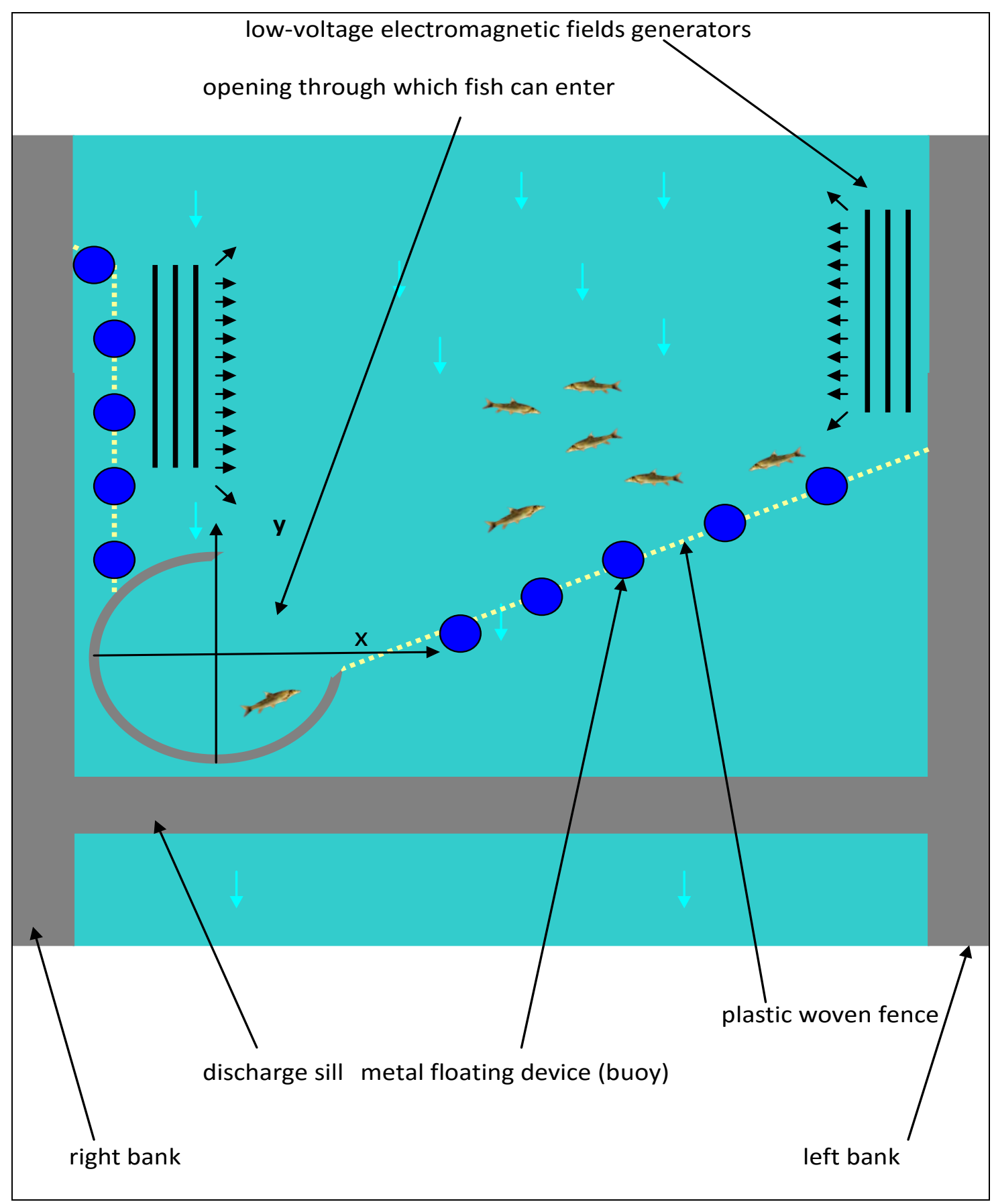

Figure 11: Positioning the circular concrete basin upstream of the discharge sill basin - indicative scheme. 
The same system with durable plastic disc is to be used except that the disc is mushroom-shaped. The disc running is to be performed by the means of an electric pulley fixed to the concrete bars (Fig. 11). Resistant plastic disc will be fixed to the circular concrete basin by using the same system as the in the case of the disc on the inclined plane. In this case we do not have any metal structure.

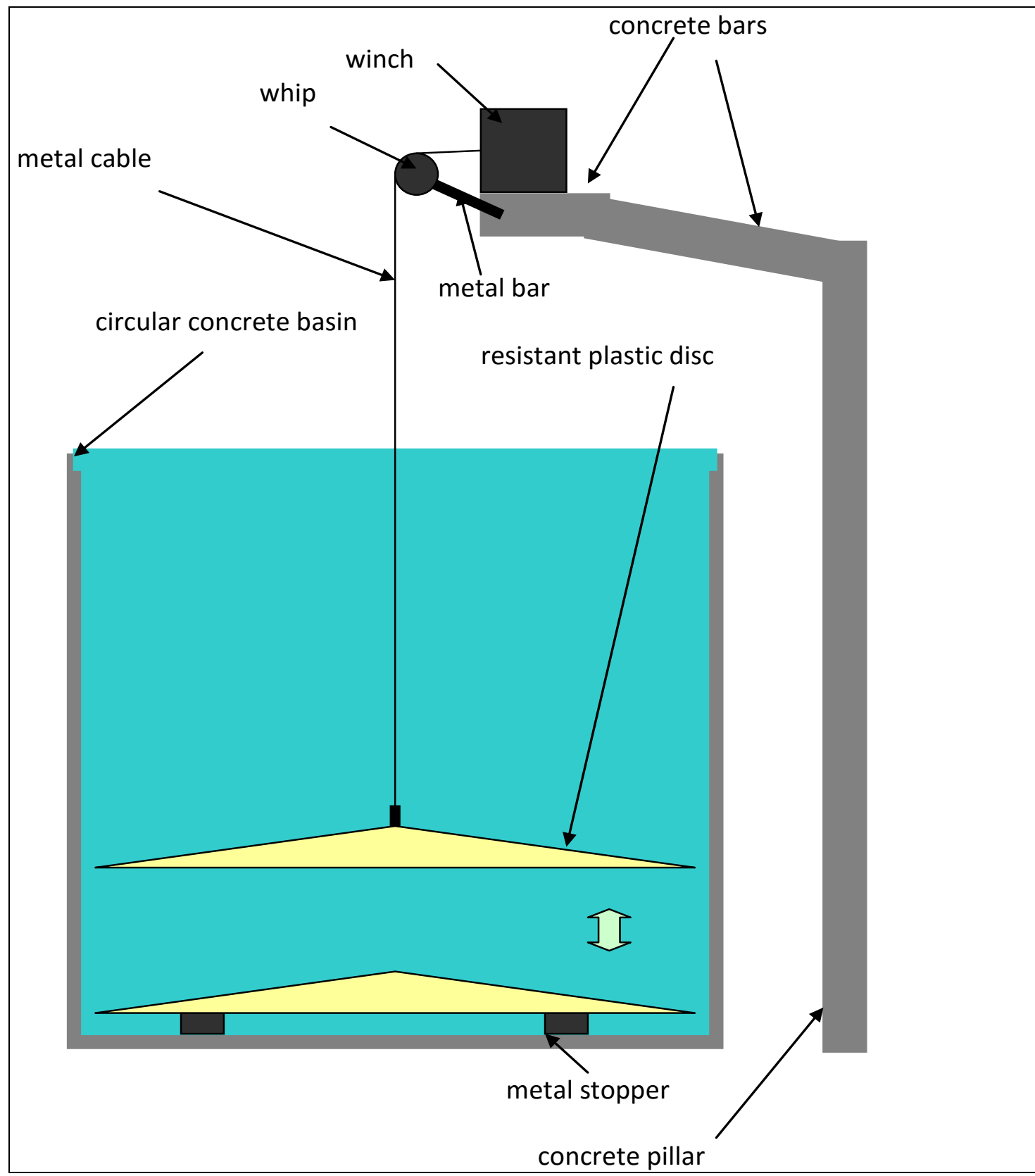

Figure 12: Positioning the winch on the concrete bar (downstream solution) basin - indicative scheme. 
The distance between the mushroom-shaped disc and the circular concrete basin is one $\mathrm{cm}$, enough for water to drain until the mushroom-shaped disc reaches the maximum height. When reaching the edge of the crest, on the outside surface of the circular concrete basin, a circular metal canal is set to undertake the ichthyofauna jumping over the basin (Figs. 12 and 13).

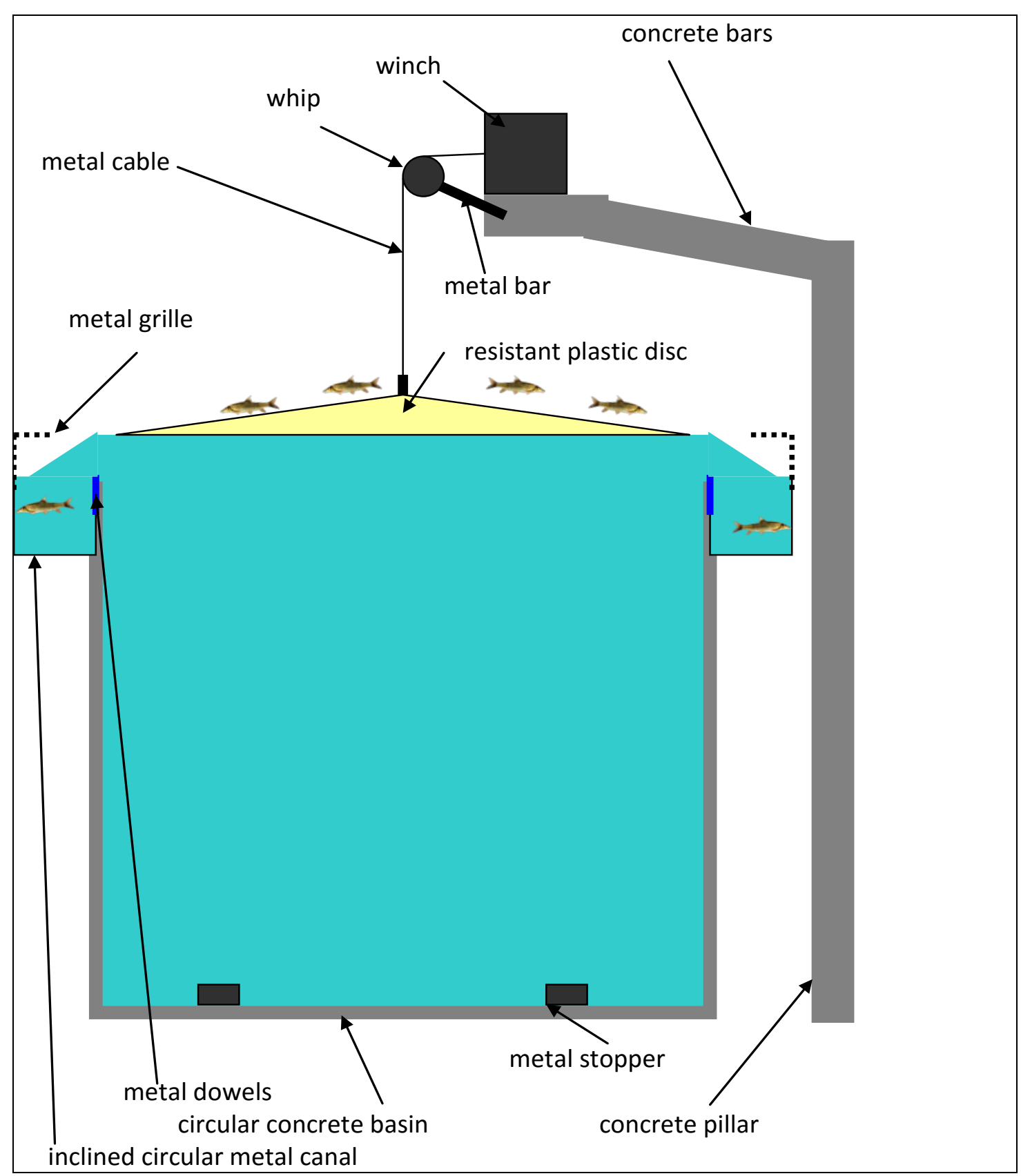

Figure 13: Positioning the circular metal canal basin

- indicative scheme. 
The circular canal is covered with metal lattice in the top in order to prevent the fish from jumping into the river and be captured at the same time. All ichthyofauna is undertaken by this inclined canal and passed above the discharge sill in total safety (Fig. 13 - inclined metal canal, circular concrete basin).

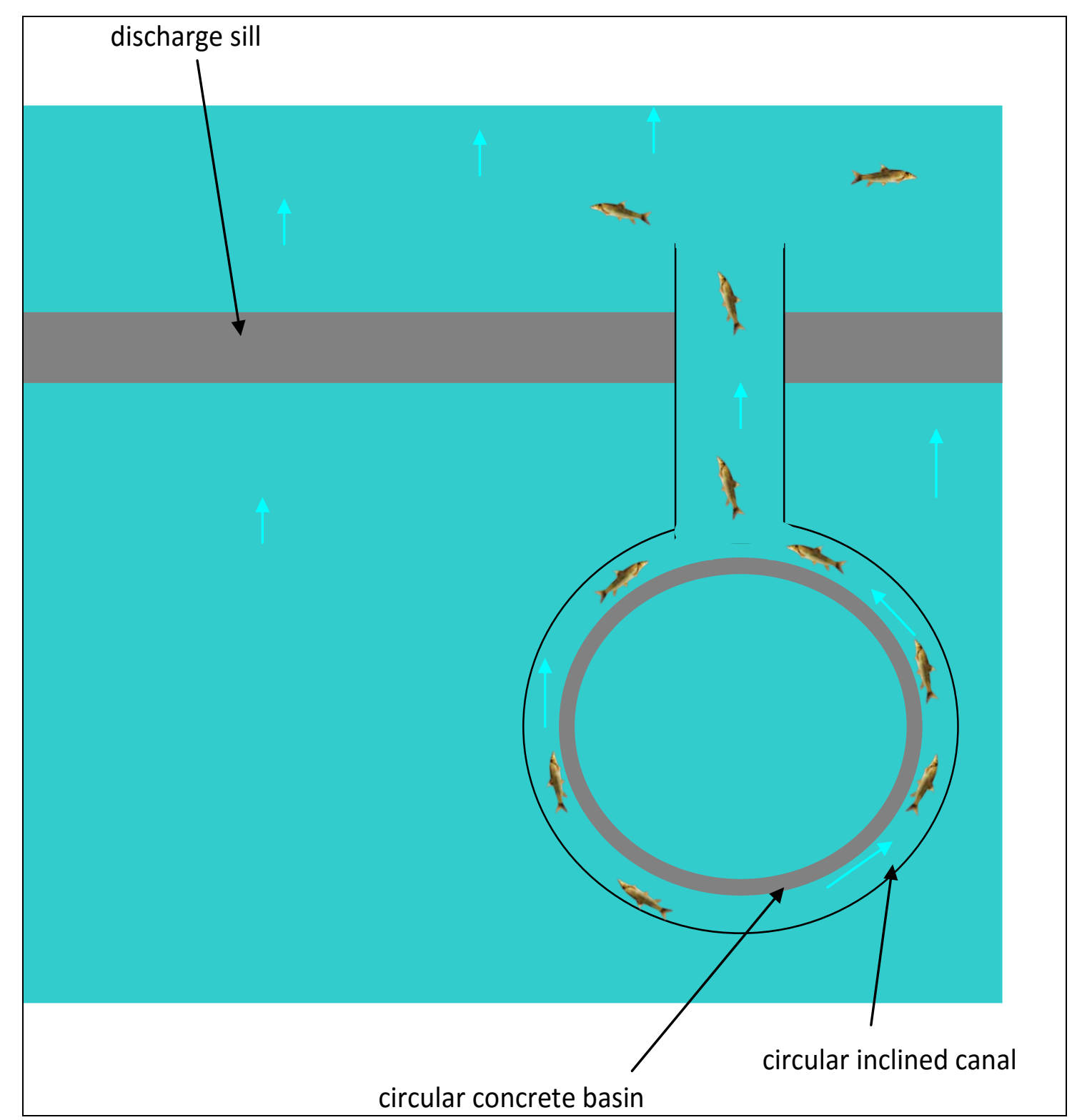

Figure 14: Positioning the circular metal canal on the circular concrete basin - indicative scheme.

This solution supports over-three-meter dams where fish do not migrate downstream as they sometimes do over some small discharge sills. This solution employs average costs. 
In order for fish to climb over the second discharge sill (Fig. 14), an escalator is to be built downstream of the discharge sill and equipped with rubber steps and parapets with variable geometry (Fig. 15).

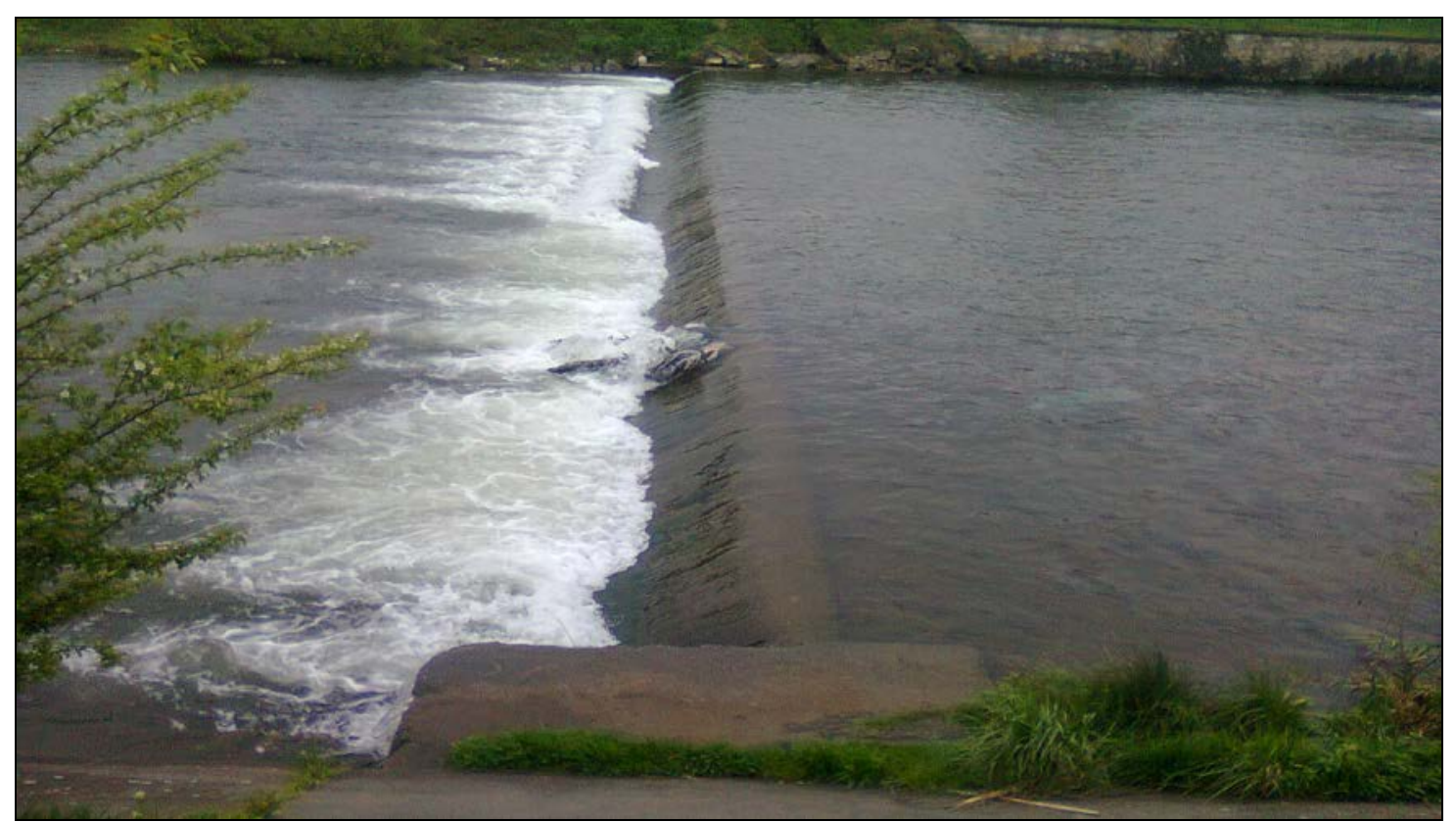

Figure 15: The second discharge sill located near Mănăştur dam.

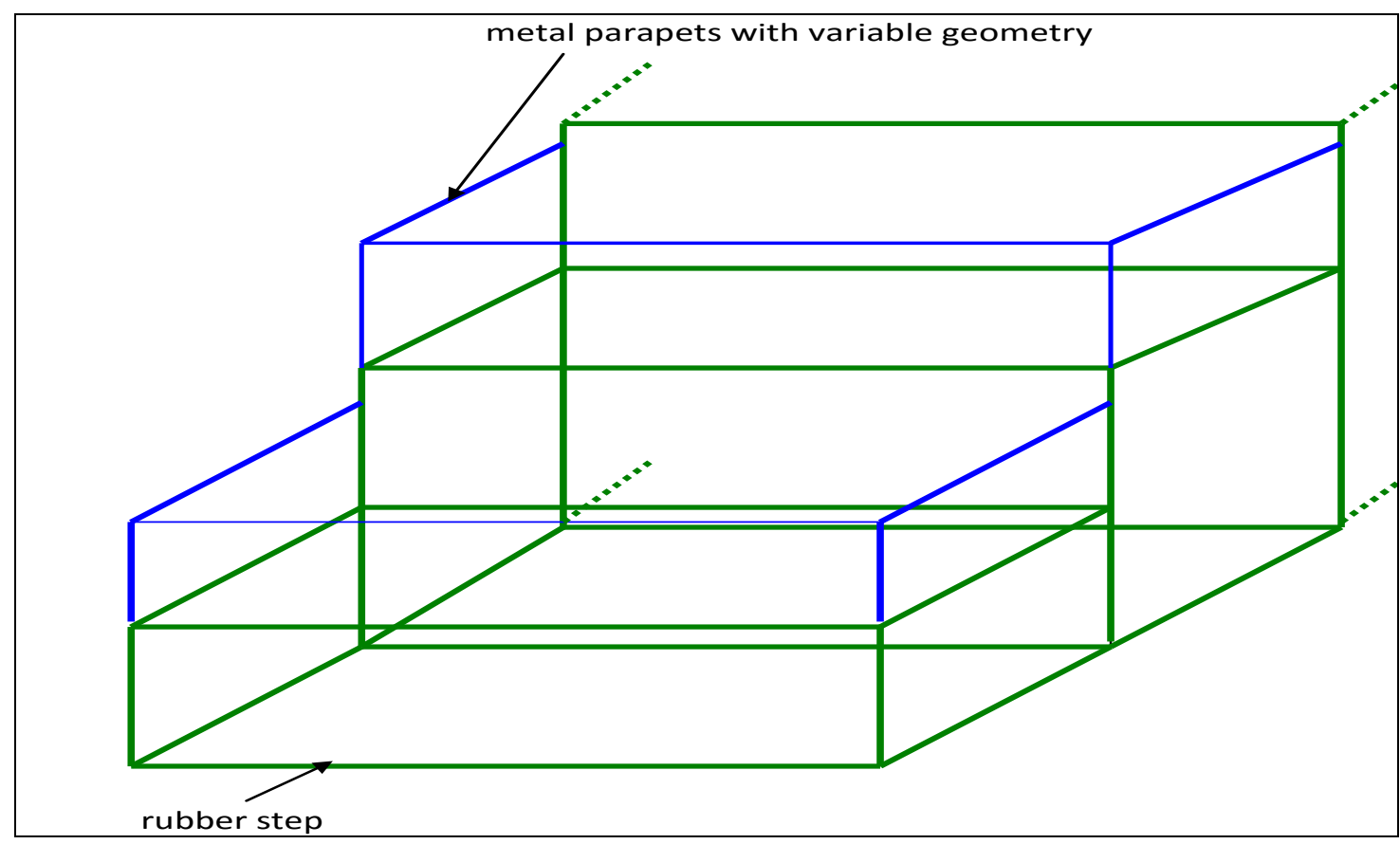

Figure 16: Escalator rubber steps and parapets with variable geometry basin - indicative scheme. 
As a solution, instead of the circular concrete basin, a rectangular parallelepiped concrete basin will be built. For fish redirecting, there will be used the same system as for the previous solutions (Fig. 16).

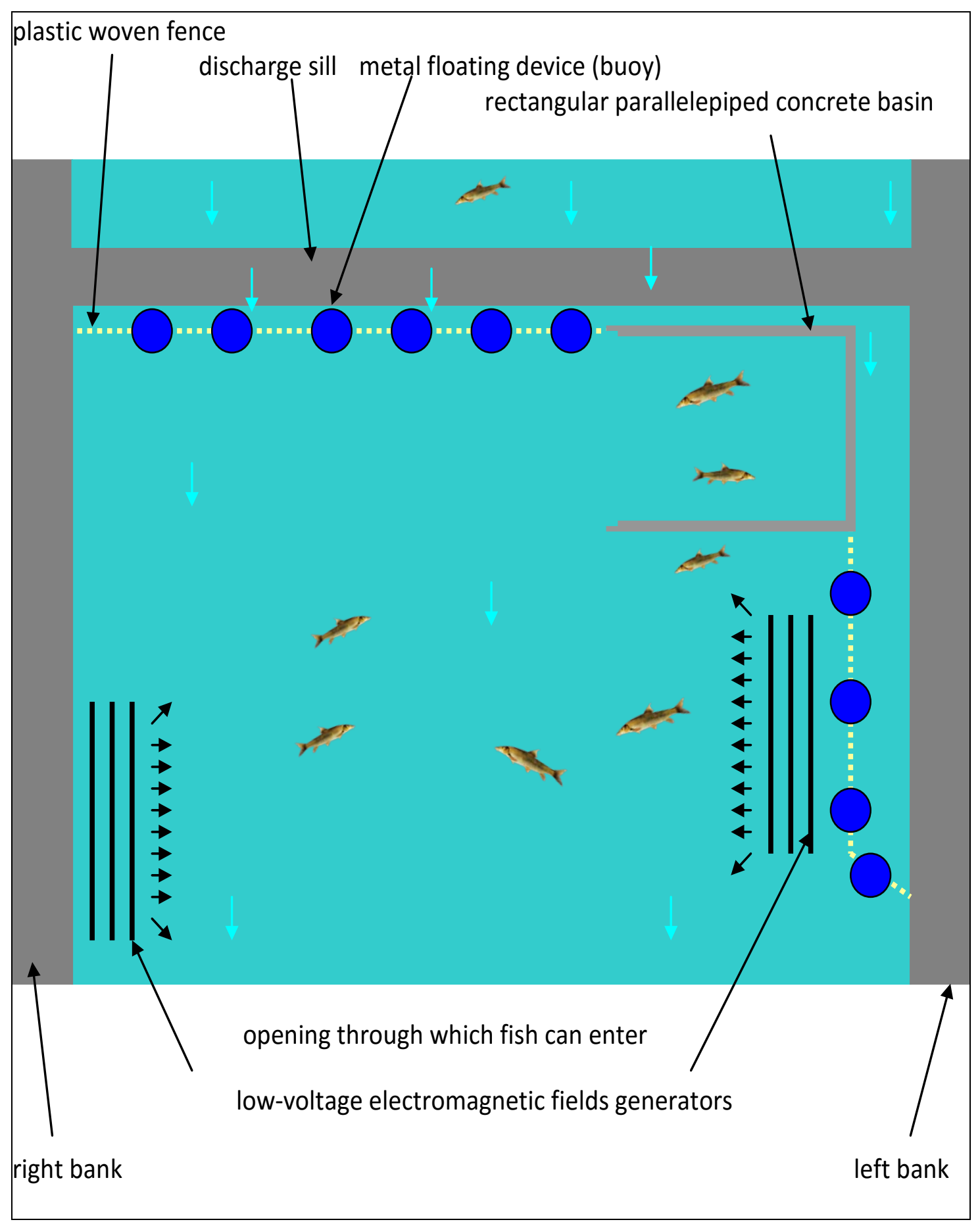

Figure 17: Positioning the rectangular parallelepiped concrete basin. 
The lower horizontal side of the escalator will be under water inside the rectangular basin and its upper horizontal side will be higher than the discharge sill. The steps will transfer the entire fish fauna towards a rectangular canal and therefore directly into the water body upstream of the discharge sill (Figs. 17 and 18).

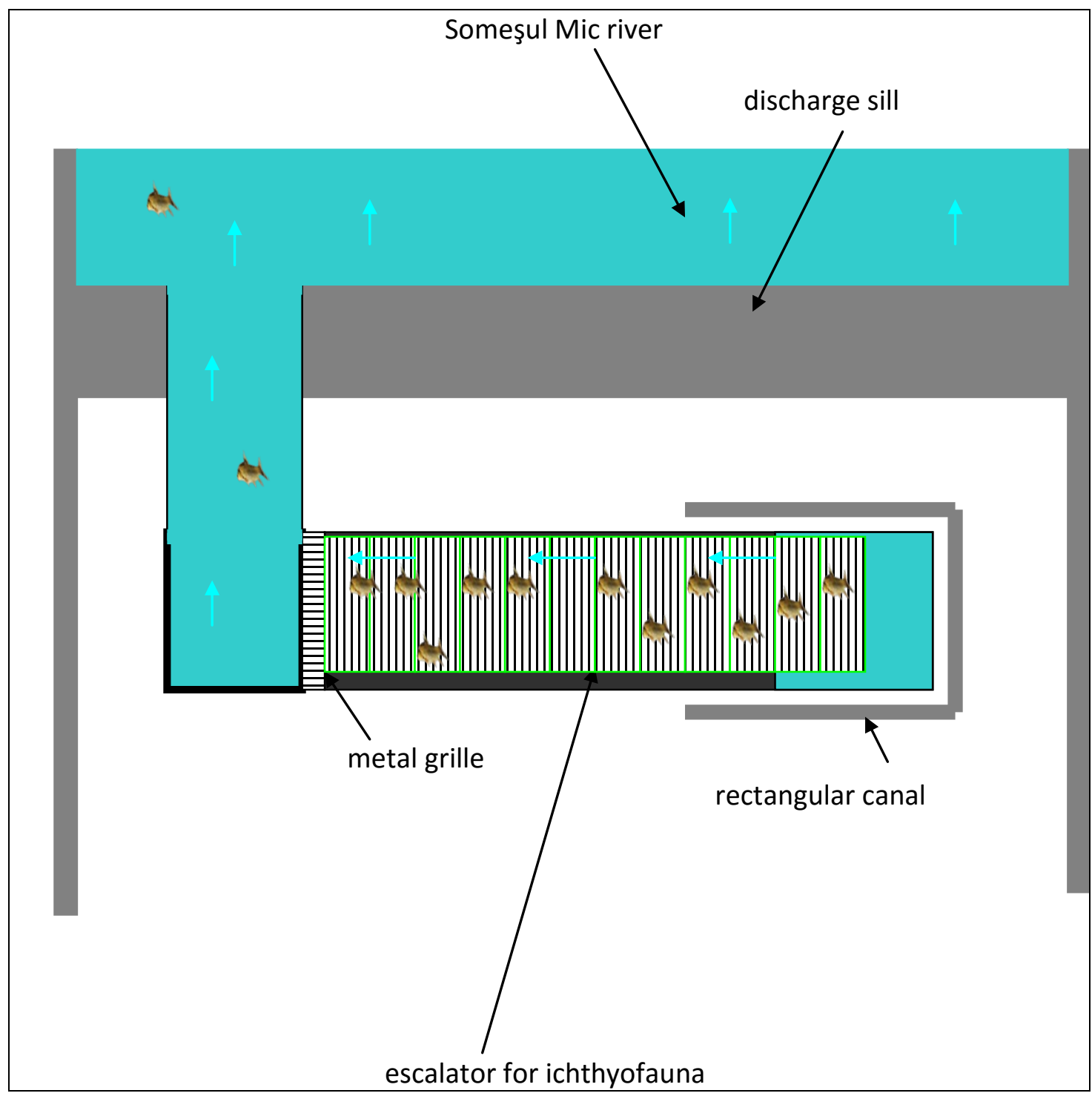

Figure 18: Positioning the escalator (horizontal plane)

- indicative scheme.

There is some two cm-metal lattice between the rectangular canal and the escalator. This escalator is lifting the ichthyofauna depending on the discharge sill height. The system is totally waterproof; costs are average but the utility is maximal. 
These designs are presented as experimental systems for further testing.

In particular, we suggest testing the systems with fishes of the size and species that are found native to the area.

Fish vary in characteristics such as attraction to fishway structures, swimming velocity, and jumping ability.

It may be, for example, that the escalator design is utilized by small benthic species that would otherwise be unable to migrate over the sill.

Although the design is intended to benefit ichthyofauna, it may also serve to inoculate upstream areas with macroinvertebrate fauna, particularly those that lack an aerial dispersal stage.

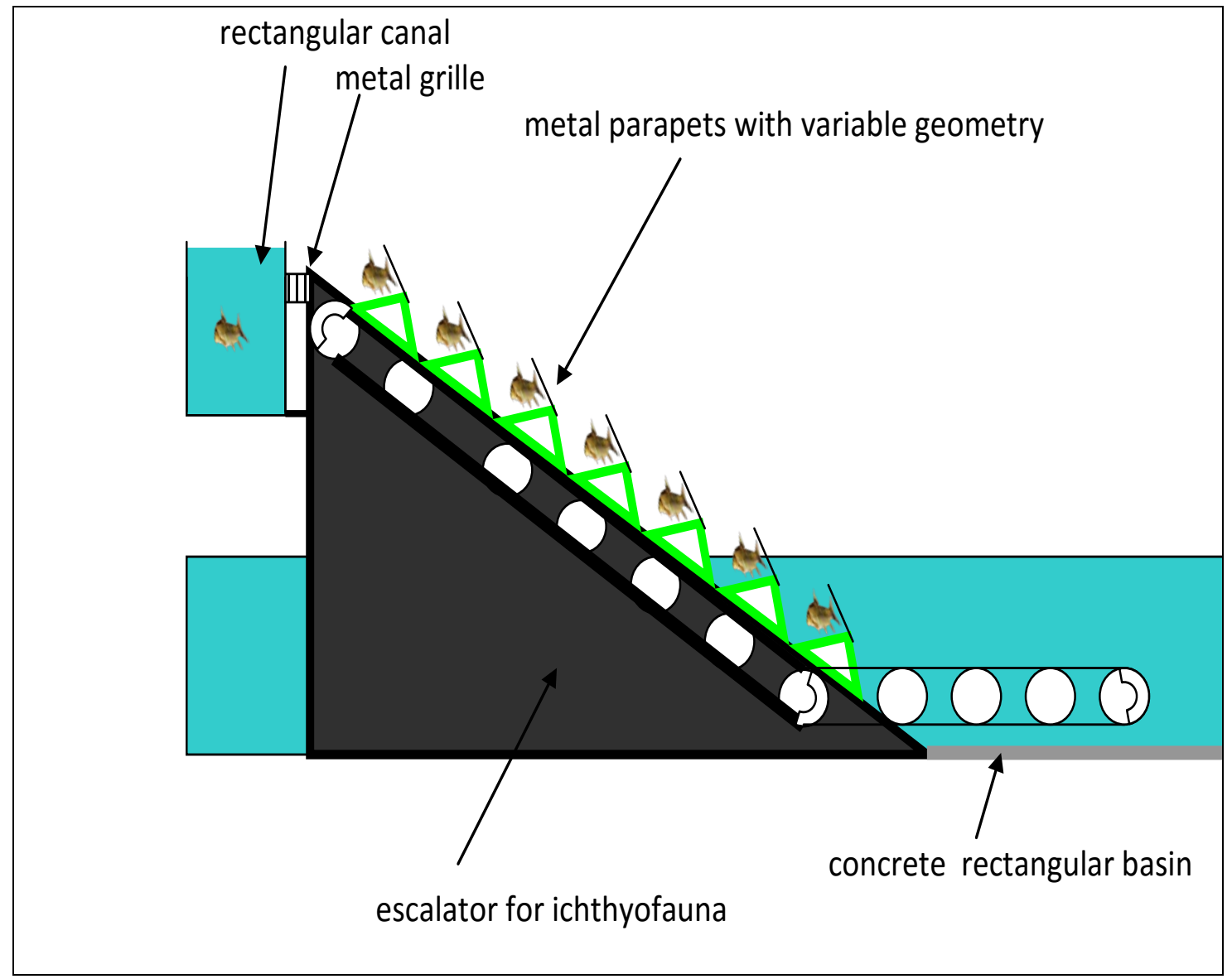

Figure 19: Positioning the escalator (inclined plane)

- indicative scheme.

This article represent a new scientific concept, a new technology for fish passage that helps a lot the fish in their migration over the discharge sills. This article represents only a design solution for building a fish passage but the results and discussions will be during construction and especially after completion. 


\section{CONCLUSIONS}

This system of fish migration upstream - downstream of the discharge sills provides longitudinal connectivity of the Someșul Mic River representing an important issue in the local lotic ecosystem restoration. All system components are classic and can be made in any country that has industry.

In addition, there is no need for a hydraulics laboratory because no velocities are calculated, relying instead on gravity.

This innovative system can also be tested with salmonids.

Because there are ichthyofauna sensors the system can work alone without human intervention.

Many fish can pass over the dam, including juvenile and older because there is no need to swim against the current of the river. 


\section{SELECTIVE REFERENCES}

1. Aadland L. P., 1993 - Stream habitat types: their fish assemblages and relationship to flow, North American Journal of Fisheries Management, 13, 790-806.

2. Bănărescu P. M., 1964 - Pisces-Osteichthyes, Fauna R. P. R., XIII, Edit. Academiei R. P. R. Bucureşti, 962. (in Romanian)

3. Bănărescu P. M. and Bănăduc D., 2007 - Habitats directive (92/43/EEC) fish species (Osteichthyes) on the Romanian Territory, Acta Ichtiologica Romanica, II, 43-78.

4. Bunt C. M., Castro-Santos T. and Haro A., 2012 - Performance of fish passage structures at upstream barriers to migration, River Research and Applications, 28, 457-478.

5. Curtean-Bănăduc A., Bănăduc D. and Bucşa C., 2007 - Watershed Management (Transylvania, Romania) - implications, risks, solutions, Strategies to Enhance Environmental Security in Transition Countries, NATO Security trough Science Series - C: Environmental Security, Springer, ISBN 978-1-4020-5995-7, 225-238.

6. Diaconu S., 1999 - Cursuri de apă, amenajare, impact, reabilitare, Edit. H. G. A., București, 2530, București. (in Romanian) 